\title{
Legal Settlement Cancellation of Umroh Jamaah Development by PT. Usmaniyah Hannien Tour
}

\author{
Lina Maulidiana ${ }^{1}$, Rendy Renaldy ${ }^{2}$ \\ \{Maulidianalina17@gmail.com, rendynotaris@gmail.com\} \\ ${ }^{1,2}$ Faculty of Law, Sang Bumi Ruwa Jurai University, Jalan Pagar Alam No.257, Langkapura, Kota Bandar \\ Lampung, Indonesia
}

\begin{abstract}
Umrah Worship Umrah is one of the activities of Worship in Islam. This service is carried out by performing several rituals of worship in the holy city of Mecca, especially in the Grand Mosque. Umrah is performing tawaf in the Kaaba and sa'i between Shofa and Marwah, after wearing the Ihram taken from miqat. Contrary to this, there are several things that cause problems, such as the cancellation of the pilgrimage that can occur because of visa problems that do not come out. However, the departure cancellations that occur by some travels, occur because of the error factor of travel, in this case it will be very detrimental to the pilgrims as consumers of travel service users. The results of this study provide an answer that in the settlement of disputes in the event of cancellation of the departure of the Umrah, the complaint is to the Ministry of Religion as the supervisor who will be the mediator between the pilgrims and the Pilgrimage Company and if not finished can file a lawsuit to the local District Court.
\end{abstract}

Keywords: Disputes, Cancellations, Umrah Pilgrims.

\section{Introduction}

Umrah Worship Umrah is one of the activities of Worship in Islam. Almost similar to the Hajj, this Worship is performed by performing rituals of worship in the holy city of Mecca, especially in the Grand Mosque. Umrah is the application of tawaf in the Kaaba and sa'i between Shofa and Marwah, after using ihram taken from miqat. It's also known as small hajj. The difference between Umrah and Hajj is in time and place. Umrah can be done at any time (every day, every month, every year) and only in Mecca, while the pilgrimage can only be done between the 8th Dzulhijjah to 12 Dhulhijjah and carried out outside the city of Mecca. As an Definition of Worship Umrah is Worship In Article 1 number 1 Regulation of the Minister of Religion Organizing Umrah Worship Trips is: a series of Umrah Worship travel activities outside the Hajj season which includes guidance, services, and protection of the Jamaah, which is carried out by the government and / or organizers of Umrah pilgrimage.

As it is known, because the community's interest in performing Umrah is very high, the administration has become a special concern by the government so that the community can perform Umrah with a sense of security and provide protection in performing Umrah. The organization of Umrah in Indonesia is regulated in Act Number 13 of 2008 concerning the Operation of Hajj, Government Regulation Number 79 of 2012 concerning the Implementation of Law Number 13 of 2008 and Regulation of the Minister of Religion of the Republic of Indonesia Number 8 of 2018 concerning Organizing Umrah Worship Trips.[1] There are several legal issues related to the cancellation of departure made by the Ibadan Umroh Organizer Company on December 22, 2017 The police arrested, Managing Director of PT. Ustmaniyah Hannien Tour, namely Farid Rosyidin (45) and Avianto Boedhy Satya, as Director of Finance. Both of them were arrested in the shop of Jalan Tegar Beriman Cibinong 
Bogor. Both of them were caught because of a fraud case of fund fraud committed by the Umrah Hannien Tour bureau for a while revealed as many as 1,800 people with total losses reaching Rp37.8 billion. In 2017 plans to dispatch 5,000 worshipers. Until now, about 3,500 people have departed. However, the remaining 1,500 pilgrims who had not left had experienced problems or had not yet departed. PT. Ustmaniyah Hannien Tour said that the obstacle so that the cancellation of the departure of Umrah pilgrims occurred because Umrah Pilgrims Visa was not issued given by the Embassy of Saudi Arabia.

There are several things that cause the problem of canceling the departure of the pilgrimage could have happened because of visa issues that did not come out other than that also the cancellation of the pilgrimage could be due to pilgrims who were pregnant or sick. However, the departure cancellations that occur by some travels, occur because of travel errors because pilgrims' money is used to fulfill the lifestyle of the travel owner. With this, it will be very detrimental to worshipers as consumers of travel service users. In the case of pilgrims and travel agents there is an agreement and the parties should do it in good faith. Umrah pilgrims as users of Umrah travel agency services need to get legal protection to protect their interests. In the agreement made between Umrah pilgrims and Umrah travel bureaus contain the rights and obligations of each party. In this case the business actor does not carry out his obligations as promised by the consumer in this case does not establish his rights in this case the consumer can claim his rights so that the business actor can fulfill his obligations.

There are several things that cause the problem of canceling the departure of the pilgrimage could have happened because of visa issues that did not come out other than that also the cancellation of the pilgrimage could be due to pilgrims who were pregnant or sick. However, the departure cancellations that occur by some travels, occur because of travel errors because pilgrims' money is used to fulfill the lifestyle of the travel owner. With this, it will be very detrimental to worshipers as consumers of travel service users. In the case of pilgrims and travel agents there is an agreement and the parties should do it in good faith. Umrah pilgrims as users of Umrah travel agency services need to get legal protection to protect their interests. In the agreement made between Umrah pilgrims and Umrah travel bureaus contain the rights and obligations of each party. In this case the business actor does not carry out his obligations as promised by the consumer in this case does not establish his rights in this case the consumer can claim his rights so that the business actor can fulfill his obligations.

\section{Methods}

This Research Is An Empirical Juridical Approach. An Empirical Juridical Approach Is Used To Analyze Various Laws And Regulations. Meanwhile Empirical Juridical Research Approach Is Research That Refers To Legal Norms And Principles Contained In Legislation And Court Decisions / Facts In The Field.[2] Ronald Dworkin Called The Research Method Also As Doctrinal Research, Which Is A Study That Analyzes Both Law As Law As It Is Written In The Book, And Law As Law As It Is Decided By The Judge Through Judicial Process.[3]

\section{Results And Discussion}

Organizers of Pilgrimage Travel in Indonesia in 2015 are regulated in the Regulation of the Minister of Religion Number 18 Year 2015 Regarding Organizing Pilgrimage. The Principle of Organizing a Umrah Service in Article Regulation of the Minister of Religion Number 18 of 2015 states that the Organization of Umrah is carried out based on the 
principles of justice, professionalism, transparency and accountability. The Purpose of Organizing Umrah Services According to Article 3 of the Minister of Religion Regulation No. 18 of 2015 provides the best possible guidance, service and protection to worshipers so that worshipers can perform their services according to Islamic law.

In line with this, PT. Usmaniyah Hannien Tour is one of the companies that have a Umrah Pilgrimage License and has an umrah offering of Rp. 16,000,000 (sixteen million rupiahs), Silver Umrah Package (starting from Rp.22,500,000 (twenty-two million and five hundred rupiah), and Gold starts from Rp.35,000,000 (thirty-five million rupiahs) With a cheap umroh promo price package, the public is interested and the congregation registers and then pays a sum of money to the PT Usmaniyah Hannien Tour. there was one that paid off and it was agreed that the departure schedule was in fact PT Usmaniyah Hannien Tour did not carry out its obligation to not dispatch the prospective pilgrims on the pilgrimage with reasons including:

1. The existence of Management Defendant I, namely PT Usmaniyah Hannien Tour, which is not good and sales of promos so that the percentage is inversely proportional;

2. Financial losses and mismanagement;

3. Do not get new investors.

PT. Usmaniyah Hannien Tour did not carry out its obligation to dispatch prospective pilgrims in accordance with the specified schedule and delivered via whatsapp +62 813-23594071. Of a total of 1800 (one thousand eight hundred) prospective pilgrims of PT Usmaniyah Hannien Tour pilgrims who have not departed as many as 575 people asked to be rescheduled and 1,225 prospective Umrah pilgrims asked for a refund refund and both requests could not be fulfilled by PT. Usmaniyah Hannien Tour, to resolve the problem that occurred on August 18, 2017, as many as 372 Candidates for the Hannien Tour made a refund agreement to PT. Usmaniyah Hannien Tour so that pilgrims' money can be returned. But after the due date Refunds but PT. Usmaniyah Hannien Tour still did not return the pilgrims money even though the prospective pilgrims had sent a summons to PT. Usmaniyah Hannien Tour, and as many as 204 Umrah Pilgrims filed a lawsuit with the Cibinong District Court against PT. Usmaniyah Hannien Tour, Farid Rosyidin (President Director of PT. Usmaniyah Hannien Tour) as Defendant II, Ridwan Agung as Defendant III, Arief Munandar as (Defendant IV), Avianto Boedy Satya (as Defendant V), Ilham Ananto Wibowo as Defendant, Ministry of Religion III Republic of Indonesia (as Co-Defendant). The details of money from 204 worshipers are as follows:

The Cibinong District Court ruled in addition to the Cibinong Negri District Court's decision

1. To declare (PT. Usmaniyah Hannien Tour) has broken its promise (default).

2. Punishes (PT. Usmaniyah Hannien Tour) pays all losses suffered by the Plaintiffs with a total of Rp. 4,886,151,877 (four billion eight hundred eighty-six million one hundred fifty-one thousand eight hundred seventy-seven rupiah);

3. Punishing the management of PT. Usmaniyah Hannien Tour is jointly and severally responsible for immediately paying the Plaintiff's losses since the case verdict obtained permanent legal force (inkracht);

4. Sentencing the Defendants to pay interest of $6 \%$ (six percent) per year from each of the Plaintiff's losses starting from the date the decision has permanent legal force.

The Cobinong District Court decided with consideration because (PT. Usmaniyah) was proven to be in breach of consideration under Article 1238 of the Civil Code which states: or for the sake of his own engagement, if this stipulates, that the debt owed must be considered negligent with the elapsed time. "Default is an achievement or promise that is not fulfilled by either party due to negligence; in this case the default was due to PT Usmaniyah not paying 
the losses of 372 prospective pilgrims and must be returned by Rp.2,244,228,424 (nine billion two hundred forty four million two hundred twenty eight thousand four hundred twenty four rupiah).

The Cibinong District Court stated that PT. The Ottomans must pay the cost of loss accompanied by interest because of someone who has defaulted, referring to Article 1248 of the Civil Code expressly stipulates that to him can be asked for reimbursement of costs, losses and interest: "Reimbursement of costs, losses and interest for not fulfilling an agreement, then begins to be obliged, if the person owes, after being declared negligent in fulfilling the agreement, continues to neglect it, or if something that must be given or made, can only be given or made within a grace period that has exceeded. "

In this case as stipulated in Article 3 paragraph (2), that: "The Second Party is obliged to Pay Off the refund to the First Party within the stipulated deadline as in Article 2." Article 3 paragraph (3) explains that "If the request cannot be fulfilled, the First Party shall be entitled to personal assets from the Directors and or from PT. Ottoman Hannien Tour that has been and will be (vide Civil Code). By not paying damages, the judge decided PT. Usmaniyah Hannien Tour to pay compensation to pilgrims with an interest of $6 \%$ with the consideration "Because there is no personal guarantee given to the Plaintiffs that proves what assets will be used as collateral for payment, thus the panel of judges considered, this matter must be followed up by giving a sentence to the Defendants to pay Compensatory Interest, that is, all interest, excluding the agreed interest. which is calculated as an additional payment of damages for the Plaintiffs. "

In addition to that Article 1267 of the Civil Code, which states: The party to whom the agreement is not fulfilled, can choose whether he, if it can still be done, will force the other party to fulfill the agreement, or whether he will demand the cancellation of the agreement, accompanied by compensation costs and flower". Based on article 1250 of the Civil Code, interest that is Moratoir Interest is compensation in the form of an amount of money, as a result of not fulfilling or being late to an agreement that contains the obligation to pay a sum of money by the debtor. This is regulated specifically in Article 1250 paragraph (1) of the Civil Code which states: "In each agreement which is solely related to payment of a sum of money, reimbursement, loss and interest only due to late implementation, only consists of interest determined by law, by not reducing specific statutory rules. The interest determined under the Act is interest at 6\% (six percent) a year. Although the judge stated that PT. Usmaniyah Hannien Tour is proven to have defaulted according to the author of PT. The Ottoman Hannien Tour also performed Acts against the Law. Acts against the law in broad teachings are interpreted as doing or not berbut contrary to or violate the subjective rights of others, the legal obligations of the perpetrators as well as the rules of decency and compliance in society.139 According to the Author PT. Usmaniyah Has committed an act against the law because it is contrary to Article 11 Paragraph (5) stating that the pilgrims must dispatch 6 months from registration but PT. The Ottomans did not dispatch their congregation in this case to have committed acts against the law, an Act could be said against the law if it fulfilled the following elements:

1. There is an element of an action

An act here is the beginning that the Umrah Pilgrimage Company will dispatch prospective Umrah pilgrims after Umrah pilgrims pay in full with a waiting system of one year or even more than one year.

2. The existence of these acts is against the law

The act of the Umrah Pilgrimage Company in this case PT Usmaniyah Hannien Tour will initially depart the pilgrims after the pilgrims pay in full with a waiting system one 
year later, but PT. The Ottomans did not dispatch the prospective pilgrims as many as 1800 pilgrims canceled to leave and 575 worshipers asked to be rescheduled and as many as 1,223 people asked for a refund and both PT Usmaniyah could not be fulfilled and 372 worshipers made a refund agreement with PT. USmaniyah Hannien Tour, but until September 30, 2017 has not been returned as much as to the detriment of pilgrims to PT. Ottoman Hannien Tour.

3. The absence of justification or excuse reasons (rechtvaardigingsground), such as the state of overmacht, self-defense, insane and others.

In this case according to the authors the owners carry out their actions consciously and in a conscious and sane state.

4. There is a loss for the victim.

In this case, according to the author in the event of the cancellation of the departure made by the company organizing Umrah worship in this case the Hannien Tour has harmed pilgrims as many as 1800 pilgrims Hannien Tour canceled leaving and pilgrims loss of Rp. 4,886,151,877 (four billion eight hundred eighty-six million one hundred fifty-one thousand eight hundred seventy-seven rupiah).

5. There is a causal relationship between deeds and losses

In the event of a cancellation of the departure of pilgrims to the pilgrimage of Hannien Tour, as many as 1800 pilgrims.

In this case, according to the author hannien tour has committed acts against the law and pilgrims Umrah Hannien Tour can request compensation. The form of compensation in tort is as follows:

1. Nominal compensation

Nominal compensation in this case losses suffered by pilgrims umroh 1800 from those who failed to leave and 575 asked for rescheduling and 1,225 worshipers asked for a refund and refunded 372 pilgrims with a total accumulation of Rp. 4,886,151,877 (four billion eight hundred eighty-six million one hundred fifty-one thousand eight hundred seventy-seven rupiah). in addition to that, the hannien tour must return all pilgrimage money.

2. Compensation compensation

Compensation compensation here is the Hannien Tour pilgrims experiencing stress because of failing to leave because many pilgrims have collected money to leave for years, but canceled leaving so that pilgrims stressed and sick, some were embarrassed because canceled departing Hannien Tour pilgrims felt ashamed because generally the neighbors and relatives already know that pilgrims will depart, but cancel departing, making the pilgrims ashamed and can be asked for compensation compensation or immaterial losses.

3. Punitive damages

This compensation can also be given to pilgrims Umrah this compensation is greater than the actual loss of Rp. 4,886,151,877 (four billion eight hundred eighty-six million one hundred fifty-one thousand eight hundred seventy-seven rupiah) is intended to give a sentence to PT. Usmaniyah Hannien so as not to happen in the future and not to repeat these actions in the future.[4]

According to the author the judge has been right in deciding the Case of PT. Usmaniyah Hannien Tour and proven default, and must pay the losses of the pilgrims by paying $6 \%$ interest from the loss and according to the Author Imposition of sanctions to the Defendants for joint responsibility to pay the losses of pilgrims is appropriate with the imposition of sanctions is expected the rights of the Umrah pilgrims can be fulfilled. Of the 1800 worshipers 
who get compensation only 204 worshipers according to the author who only get compensation only as many as 204 remaining do not, and the authors assume that PT. Usmaniyah Hannien Tour did Acts against the law, but in this case did not get compensation. Only 204 pilgrims were obtained. In addition to that the system of organizing the Umrah Worship runs well it is said if it fulfills the three elements according to Lawrence M. Friedman stated that the three elements of the legal system consist of legal structure, legal substance, and legal culture, as follows:

Legal structure (legal structure) is applied in legal entities, in relation to law enforcement agencies. in this case relating to legal institutions namely the Ministry of Religion, the Police and all Law Enforcement and Institutional Officers of the Ministry must maximize performance and perform their functions and duties in accordance with the Statutory Regulations in this case conducting Supervision of the Pilgrimage Company Cancellation of Departure of Umrah in the future. In addition, it is assisted by other law enforcement officers so that similar problems do not occur in the future.[5]

Besides the substance of the law (legal substance) is the most important factor in a country of law. Written in the form of legal regulations to seek legal certainty through statutory regulations. In this case there has been a Regulation regarding the Organizers of Umrah in this Law Number 8 of 1999 Concerning Consumer Protection, Law Number 13 of 2008 concerning the Operation of Hajj and Umrah, Government Regulation Number 79 of 2012 Concerning Implementing Regulations of the Act Number 13 of 2008 concerning the Organization of Hajj and Umrah and Regulation of the Minister of Religion Number 8 of 2018 concerning the Organization of Hajj and Umrah. apart from the Regulations and policies of the Organizing Company Must make a clear and detailed Agreement and implemented in good faith. Besides that, legal culture is the determining factor of a rule. The legal culture here consists of the legal culture of law enforcement officers and the public. The government in this case is trying to maximize its function and authority so that it runs well, besides that the public is also advised not to be easily tempted by the cheap umrah package prices so that it does not happen in the future.

\section{Conclusion And Recommendation}

Settlement of disputes in the event of cancellation of the departure of Umrah complains to the Ministry of Religion as the supervisor who will be the mediator between the pilgrims and the Umrah Pilgrimage Company and if not finished can file a lawsuit to the local District Court.

\section{References:}

[1] "No Title." [Online]. Available: https://tirto.id/first-travel-hingga-hannien-tour-kenapapenipuan-umrah-berulang-cCGb.

[2] D. P. Melati, A. Armandoni, and R. Renaldy, "INDONESIAN CRIMINAL LAW CONSTRUCTION BASED ON,” pp. 285-291, 2018.

[3] D. P. Melati, A. Armandoni, and R. Renaldy, "POLICE POLICY IN LAW ENFORCEMENT ( CASE STUDY ON DISKRESSION APPLICATION ON DELIK NOT )," no. 48, pp. 308-314, 2018.

[4] K. Dimyati, eorisasi Hukum Studi Tentang Pemikiran Hukum di Indonesia 1945-1990. Yogyakarta: Genta Publishing, 2010. 
[5] E. Makarim, Kompilasi Hukum Telematika. Jakarta: PT RajaGrafindo Persada, 2003. 